\title{
Are Oil Prices and Remittance Outflows Asymmetric? Evidence From Saudi Arabia
}

\author{
Selçuk Akçay ${ }^{1}$ • \\ 1 Economics, Afyon Kocatepe University, Turkey \\ Keywords: saudi arabia, remittances, oil price, asymmetry \\ https://doi.org/10.46557/001c.18948
}

\section{Energy RESEARCH LETTERS}

Vol. 2, Issue 1, 2021

Understanding the nexus between oil prices and remittance outflows is critical for both remitting and recipient countries. This is the first study that examines the asymmetric impact of oil prices on remittance outflows for Saudi Arabia. Relying on the non-linear autoregressive distributed lag model and taking advantage of yearly data over the period 1980-2018, we document that: (i) oil prices are asymmetrically related to remittance outflows but only in the long-run; and (ii) positive innovations in oil prices are conducive to remittance outflows, whereas negative innovations do not affect remittance outflows significantly.

\section{Introduction}

Saudi Arabia is known for its oil-based economy and oil has been a key driver of the country's economic development. Indeed, oil constitutes roughly $40 \%$ of GDP, nearly $70 \%$ of fiscal revenues, and almost $80 \%$ of exports (IMF, 2019 , p. 4). Due to its oil-based economy and lack of labor force, Saudi Arabia draws many migrant workers mainly from Egypt, India, Pakistan, Bangladesh, and Indonesia. The total number of international migrants increased from $5,203.4$ thousand (25.6\% of the total population) in 2000 to $13,123.3$ thousand (38.3\% of the total population) in 2019 , representing a $149 \%$ increase over the past twenty years (United Nations, Department of Economic and Social Affairs, Population Division, 2019). International migrant workers in Saudi Arabia remit a sizable amount of money to their home countries. In 2018, for instance, \$US33.882 million was remitted from Saudi Arabia, accounting for about $4.3 \%$ of the country's GDP (World Bank, 2020).

The increasing amount of remittance outflows particularly in oil-based economies, such as those from the Gulf Cooperation Council (GCC) countries, have raised interest in investigating their determinants. According to Naufal \& Genc (2012), there are micro and macro motives for remittance outflows in the GCC countries. The micro motives include "no citizenship path, no land ownership, limited family reunification, and a temporary guest worker program" (p.90). On the other hand, the macro drivers include large oil reserves, small population, geographic location, and stability. Besides the aforementioned drivers, some specific macroeconomic factors of host countries are also used as drivers of remittance outflows. These include migrant wages, marginal propensity to remit, migrant labor supply (Snudden, 2019), money supply, trade and capital account openness, changes in the exchange and inflation rates, volatilities in the exchange and inflation rates (Cooray \& Mallick, 2013), and financial development (Akçay, 2019).

This study aims to explore the role of the oil prices in shaping remittance outflows in Saudi Arabia with a focus on understanding whether the nexus is asymmetric/nonlinear. Saudi Arabia is an interesting case study due to a range of reasons. First, as mentioned above, Saudi Arabia's economy relies heavily on oil. Second, India-Saudi Arabia, Pakistan-Saudi Arabia, Bangladesh-Saudi Arabia, and Indonesia-Saudi Arabia migration corridors were among the top twenty migration corridors in the world (World Bank, 2016). Third, Saudi Arabia is the third-largest remittance sending country worldwide and the Saudi Arabia-India remittance corridor is in the top ten in the world. Finally, research on the asymmetric nexus between oil prices and remittance outflows is non-existent in Saudi Arabia.

Given that oil-rich-GCC countries host millions of foreign workers, according to Snudden (2018), migration flows, remittance outflows, and oil prices are intrinsically associated. The plausible mechanism is as follows: an increase in oil prices (positive shocks) can generate a sizable amount of oil revenues, leading to higher investments and a growing economy. As a result, the demand for migrant workers will increase, which in turn translates into higher remittance outflows (Naufal \& Termos, 2009). That being said, one could hypothesize a positive association between remittance outflows and increases in oil prices. However, what about the impact of negative oil price shocks on remittance outflows? According to conventional wisdom, persistent low oil prices (negative shocks) can hamper economic activities in oil-exporting economies by decreasing oil revenues. Correspondingly, the demand for migrant workers decreases, which in turn can lead to reduction in remittance outflows to migrant worker countries. Indeed, in a recent study, Kabundi \& Ohnsorge (2020) document that oil price plunges are detrimental to output losses in energy-exporting emerging markets and developing economies. Accordingly, one could hypothesize that negative shocks in oil prices reduce remittance outflows. However, from Figure 1 which displays the evolution of the growth of remittance outflows and oil prices in Saudi Arabia, the story is differ- 
ent. Indeed, Figure 1 shows that the relationship between oil prices and remittance outflows is asymmetric rather than symmetric in some periods over the sample 1980-2018.

With the above in mind, this study postulates that the association between remittance outflows and oil prices might be asymmetric. Asymmetry emerges when positive and negative innovations in oil prices affect remittance outflows in ways that are distinct from a symmetric/linear fashion. Why should oil prices asymmetrically affect remittance outflows? The nonlinear effect of oil prices on remittance outflows can be explained through the oil prices-economic activity asymmetry nexus. Oil prices-economic activity asymmetry nexus revolves around three theoretical channels, namely costly sectoral reallocation, precautionary savings, and irreversible investment (Herrera et al., 2015). First, the costly sectoral reallocation channel occurs when oil price changes reallocate capital and labor from shrinking industries to boosting industries. Accordingly, costly industrial reallocation might heighten the recessionary impact of a decrease in an oil price change and alleviate the expansionary impact of an increase in an oil-exporting country. Second, proponents of the precautionary saving theory claim that a decline in oil price might increase negative expectations about future employment and income, hence causing an increase in precautionary savings, which translates into a decrease in production through a demand-driven decline in an oil-exporting country. Since a decrease in oil price is not directly related to higher uncertainty about the future, this theory suggests asymmetry. Finally, followers of the irreversibility of investment theory believe that heightened uncertainty about oil supply and energy prices may discourage consumers from spending on energy-intensive consumer goods, like automobiles and entrepreneurs to delay their spending on capital goods. Thus, high uncertainty could mitigate the expansionary impact of an oil price surge and aggravate the recessionary impact of a price decline in an oil-exporting country (Plante \& Traum, 2012).

Although there are quite extensive studies on the linear and nonlinear impacts of oil prices on the remittance inflows (Abbas, 2020; Akçay \& Karasoy, 2019), there have been few attempts to examine the impacts of oil prices on remittance outflows. For instance, Naufal \& Termos (2009) document that positive innovations in oil prices have a positive impact on remittance outflows. In another study, focusing on Saudi Arabia and Russia, Snudden (2018) reports that an increase in oil price stemming from increased foreign demand for oil hampers remittance outflows in Saudi Arabia, whereas it promotes in Russia.

It should be noted that the aforementioned studies assume a linear/symmetric association between remittance outflows and oil prices. Indeed, research on the nonlinear impacts of oil prices on remittance outflows is scarce. Akçay (2019) is the only study that considers asymmetry between oil prices and remittance outflows. Taking Oman as a case study, the author documents that remittance outflows are positively affected by an increase in oil prices, but a decrease has no significant impact.

Drawing on annual data over the period 1980-2018 and using a non-linear autoregressive distributed lag model (NARDL) proposed by Shin et al. (2014), we document that

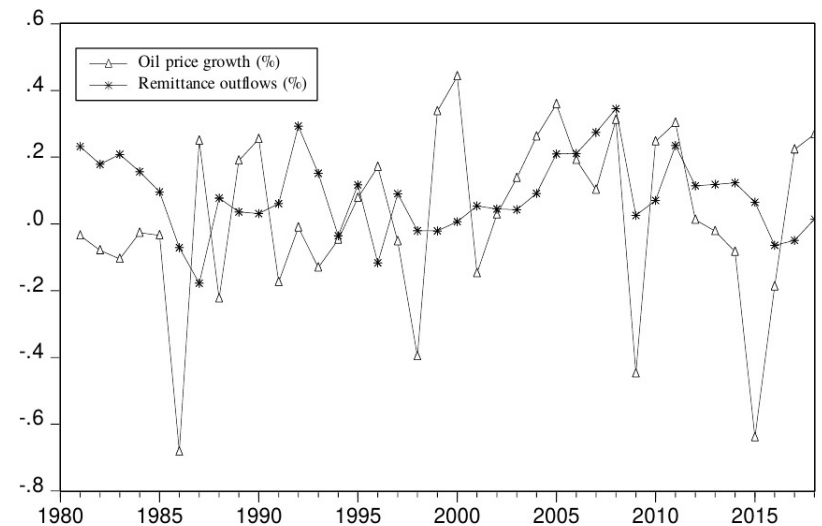

Figure 1. The growth rate of oil prices and remittance outflows

oil prices are related to remittance outflows. The relation is asymmetric only in long run, suggesting that positive innovations in oil prices promote remittance outflows, whereas negative innovations do not affect remittance outflows significantly. The present study adds to the literature in two aspects. First, it is the first study that probes the responses of remittance outflows to oil price changes in a major oilexporting country. Second, it applies the NARDL method, which enables us to gauge the impacts of positive and negative changes in oil prices on remittance outflows separately. According to this methodology, asymmetry prevails when positive and negative changes have different impacts on remittance outflows.

The remaining part of the study is framed as follows. The empirical framework and data are given in Section 2, while section 3 is devoted to results and discussion. Section 4 concludes.

\section{Data and Empirical Strategy}

Following Akçay (2019), we consider the following model to explore the existence of asymmetries in the relationship between remittance outflows and oil price innovations.

$$
\begin{aligned}
\text { remout }_{t}= & \alpha_{0}+\alpha_{1} \text { gdpgr }_{t}+\alpha_{2} f d_{t} \\
& +\alpha_{3} \text { inf }+\alpha_{4} \text { oilp } \\
t & +\varepsilon_{t}
\end{aligned}
$$

where remout $t_{t}$ is the remittance outflows (current US\$), $g d p g r_{t}$ stands for the GDP growth rate, $f d_{t}$ measures financial development, $\inf f_{t}$ is a measure of inflation (a proxy for macroeconomic instability), oilp $t$ measures the average of oil prices (Dubai, Brent, and WTI spot crude oil prices, US\$ per barrel) and $\varepsilon_{t}$ is the disturbance term. The source of remittance outflows, GDP growth rate, and inflation data is the World Bank's World Development Indicators (World Bank, 2020). Data on financial development is taken from Svirydzenka (2016). The oil price data is retrieved from the "Our World in Data" (https://ourworldindata.org/grapher/ crude-oil-prices). Notice that remittance outflows and oil price series enter the model in logarithmic form.

Following Shin et al. (2014), we decompose oil price innovations as oilp $t_{t}^{+}$and oilp $p_{t}^{-}$where the former reflects positive and the latter denotes negative innovations and they are generated as follows: 
Table 1. Lee Strazicich LM unit root test results

\begin{tabular}{|c|c|c|c|c|c|}
\hline Variables & Level & Break Points & $1^{\text {st }}$ Dif. & Break Points & Integration Order \\
\hline remout & -2.824 & 2006-2010 & $-3.987^{* *}$ & $1984-2003$ & $\mathrm{I}(1)$ \\
\hline gdpgr & $-4.264^{* * *}$ & $1984-2003$ & - & - & $\mathrm{I}(0)$ \\
\hline$f d$ & -2.769 & $2007-2014$ & $-5.508^{* * *}$ & $1983-1991$ & $\mathrm{I}(1)$ \\
\hline inf & -2.749 & $1995-2007$ & $-5.835^{* * *}$ & $1983-2001$ & $\mathrm{I}(1)$ \\
\hline oilp & -1.984 & $1985-2004$ & $-6.344^{* * *}$ & $1988-2010$ & $I(1)$ \\
\hline
\end{tabular}

Notes: This table reports the Lee-Strazicich LM unit root test for both levels and first difference of variables. Break dates and test statistics are provided. The final column reports the order of integration. Finally, ${ }^{* * * *} \mathrm{p}<0.001$ and ${ }^{* * *} \mathrm{p}<0.05$

$$
\begin{aligned}
& o i l p_{t}^{+}=\sum_{j=1}^{t} \Delta o i l p_{j}^{+}=\sum_{j=1}^{t} \max \left(\Delta o i l p_{j}, 0\right), \\
& o i l p_{t}^{-}=\sum_{j=1}^{t} \Delta o i l p_{j}^{-}=\sum_{j=1}^{t} \min \left(\Delta o i l p_{j}, 0\right)
\end{aligned}
$$

Our NARDL model that incorporates positive and negative innovations in oil prices with other control variables are as follows:

$$
\begin{aligned}
\Delta \text { remout }_{t}= & \beta_{0}+\sum_{i=1}^{a} \beta_{1 i} \Delta \text { remout }_{t-i} \\
& +\sum_{i=1}^{b} \beta_{2 i} \Delta g d p g r_{t-i}+\sum_{i=1}^{c} \beta_{3 i} \Delta f d_{t-i} \\
& +\sum_{i=1}^{d} \beta_{4 i} \Delta i n f_{t-i}+\sum_{i=0}^{e} \beta_{5} \Delta \text { oil }_{t-i}^{+} \\
& +\sum_{i=0}^{e} \beta_{6} \Delta \text { oilp }_{t-i}^{-}+\lambda_{0} \text { remout }_{t-1} \\
& +\lambda_{1} \text { gdpgr }_{t-1}+\lambda_{2} f d_{t-1} \\
& +\lambda_{3} \text { inf }_{t-1}+\lambda_{4} \text { oilp p p } \\
& +\lambda_{5} \text { oilp }_{t-1}^{-}+u_{t}
\end{aligned}
$$

where $a, b, c, d$, and $e$ are the lag orders.

The application of the NARDL proceeds in four steps. Estimation of Equation (3) by the OLS is the first step. Testing for co-integration among the variables is the second step. To this end, the null hypothesis of no co-integration $\left(H_{0}: \lambda_{0}=\ldots=\lambda_{5}=0\right)$ is tested against the alternative hypothesis $\left(H_{1}: \lambda_{0} \neq \ldots \neq \lambda_{5} \neq 0\right)$ using the $F$-test. If the calculated $F$-statistic exceeds the critical values (lower bound and upper bound) tabulated by Pesaran et al. (2001), the null hypothesis can be rejected. The third step requires testing the long-run and short-run asymmetry by employing the Wald test. The long-run and short-run null hypotheses are $\left(\frac{\lambda_{4}}{-\lambda_{0}}=\frac{\lambda_{5}}{-\lambda_{0}}\right),\left(\sum \beta_{5 i}=\sum \beta_{6 i}\right)$, respectively. If the aforementioned null hypotheses are rejected, we can conclude that the impact of oil price changes on remittance outflows is asymmetric in both the short- and long-run.

\section{Results and Discussion}

As a starting point, we test the stationarity of all variables to confirm that no variable is $I(2)$, which is an essential requirement for the NARDL approach. Given that our sample period covers episodes of swings in the price of crude oil, we implement the Lee \& Strazicich (2003) unit root test that allows for potential structural breaks. The re- sults appear in Table 1, verifying that none of the variables is $I(2)$. The break points (1985-2004) obtained from the test for oil prices are included in the model as dummy variables. The break in 1985 can be ascribed to a drastic reduction in oil production by Saudi Arabia. The break in 2004 can be associated with the supply bottlenecks caused by geopolitical uncertainties, such as numerous acts of sabotage in Iraq and civil conflicts in Nigeria.

Table 2 reports our main findings. The results documented in Panel A confirm the existence of co-integration among the variables. The Wald tests presented in Panel B lend support to the non-linear relationship between remittance outflows and oil prices but only in the long-run. This result implies that the impact of oil price increases and decreases on remittance outflows is different.

The short-run results that appear in Panel C show that both positive and negative innovations in oil prices do not affect remittance outflows significantly. On the other hand, the long-run results summarized in Panel D indicate that remittance outflows respond positively to positive changes in oil prices, suggesting that a $1 \%$ increase in oil price leads to a $0.92 \%$ increase in remittance outflows. This result is consistent with Akçay (2019). The oilpt variable carries a negative but statistically insignificant coefficient, suggesting that negative innovations in oil prices do not influence remittance outflows, corroborating the findings of Akçay (2019). Furthermore, the control and dummy variables do not have a statistically significant impact on remittance outflows.

The diagnostic test results given in Panel E suggest that our estimated NARDL model is well-specified, reflecting the robustness of our model.

\section{Conclusions}

Saudi Arabia has been a major source of remittance for the past few decades. However, the question of how changes in oil prices influence remittance outflows has not been investigated in this literature. This is the first study that investigates whether there is an asymmetric relationship between oil prices and remittance outflows in the case of Saudi Arabia. To do so, we used annual data for the period 1980-2018 and employed the NARDL procedure. Our main results are twofold. First, we found that the reaction of remittance outflows to oil prices is asymmetric but only in the long-run. Second, while positive innovations in oil prices enhance remittance outflows, negative innovations 
Table 2. NARDL model results

A) Bounds F-test for co-integration

\begin{tabular}{|c|c|c|c|c|c|c|}
\hline \multirow{3}{*}{ Model } & \multirow{3}{*}{ s } & \multirow{3}{*}{ F-stat. } & \multicolumn{4}{|c|}{ F-Critical Values } \\
\hline & & & \multicolumn{2}{|c|}{$\% 5$} & \multicolumn{2}{|c|}{$\% 1$} \\
\hline & & & $\mathrm{I}(0)$ & $\mathrm{I}(1)$ & $\mathrm{I}(0)$ & $\mathrm{I}(1)$ \\
\hline $\begin{array}{l}\text { F(remout | oilp }{ }^{+} \text {,oilp, gdpgr, fd, inf, dum } 1985 \text {, } \\
\text { dum2004) }\end{array}$ & 2 & $4.566^{* * *}$ & 2.60 & 3.84 & 2.96 & 4.26 \\
\hline B) Asymmetry tests & & Wald test & & & & $p$-values \\
\hline Wald-L & & $38.16^{* * *}$ & & & & 0.000 \\
\hline Wald-S & & 2.78 & & & & 0.109 \\
\hline C) Short-run estimates & Coefficients & $t$-statistics & & & & $p$-values \\
\hline remout $_{t-1}$ & $-0.305^{* * *}$ & -2.99 & & & & 0.007 \\
\hline oilp $_{t-1}^{+}$ & $0.280^{* * *}$ & 3.68 & & & & 0.001 \\
\hline oilp $_{t-1}^{-}$ & 0.086 & 1.41 & & & & 0.173 \\
\hline sremout $_{t-1}$ & 0.098 & 0.60 & & & & 0.557 \\
\hline$\Delta o i l p_{t}^{+}$ & 0.039 & 0.26 & & & & 0.799 \\
\hline$\Delta$ oilp $_{t-1}^{+}$ & -0.237 & -1.63 & & & & 0.118 \\
\hline$\Delta o i l p_{t}^{-}$ & 0.105 & 0.92 & & & & 0.367 \\
\hline$\Delta o i l p_{t-1}^{-}$ & 0.171 & 1.69 & & & & 0.104 \\
\hline gdpgr & 0.010 & 1.09 & & & & 0.288 \\
\hline$f d$ & -0.371 & -0.91 & & & & 0.374 \\
\hline $\inf$ & 0.001 & 0.48 & & & & 0.638 \\
\hline dum1985 & 0.037 & 0.36 & & & & 0.721 \\
\hline dum2004 & -0.071 & -0.79 & & & & 0.437 \\
\hline constant & $2.181^{* * *}$ & 3.13 & & & & 0.005 \\
\hline D) Long-run estimates & Coefficients & $t$-statistics & & & & $p$-values \\
\hline oilp ${ }^{+}$ & $0.916^{* * *}$ & 35.19 & & & & 0.000 \\
\hline oilp- & -0.284 & 1.391 & & & & 0.250 \\
\hline E) Diagnostic tests & & Value & & & & $p$-value \\
\hline Breusch-Godfrey Serial Correlation. LM Test & & 10.6 & & & & 0.833 \\
\hline Ramsey RESET Test & & 1.579 & & & & 0.225 \\
\hline Jarque-Bera Normality Test & & 1.225 & & & & 0.542 \\
\hline Breusch-Pagan-Godfrey Heteroskedasticity Test & & 2.169 & & & & 0.141 \\
\hline F-statistics & & $3.61^{* * *}$ & & & & 0.003 \\
\hline $\mathrm{R}^{2} /$ Adjusted $\mathrm{R}^{2}$ & & $0.67 / 0.48$ & & & & - \\
\hline
\end{tabular}

Notes: This table reports results organized into five panels. Panel A has the cointegration test results; Panel B has the asymmetry test results; the short-run estimates are in Panel C while Panel D contains the long-run estimates; and, finally, Panel E contains diagnostic tests. . The critical values (Case III: unrestricted intercept and no trend) are from Pesaran et al. (2001), $s$ and $t$ stand for the number of explanatory variables and the lag length respectively. Wald- $L$ and Wald- $S$ denote the Wald tests for asymmetry in the long- and short run, respectively. Finally, ${ }^{* * * * *} \mathrm{p}<0.001,{ }^{* * *} \mathrm{p}<0.05$ and $* \mathrm{p}<0.1$

have no statistically significant effects. This study provides evidence on oil price-remittance outflows nexus for one of the largest remitting countries: future studies can explore the second type of asymmetry that considers the magnitude of oil price innovations (whether oil price innovations are large or small) on remittance outflows. 


\section{REFERENCES}

Abbas, S. (2020). Impact of oil prices on remittances to Pakistan from GCC countries: Evidence from panel asymmetric analysis. OPEC Energy Review, 44(2), 205-223. https://doi.org/10.1111/opec. 12180

Akçay, S. (2019). Does oil price asymmetrically impact remittance outflows? The case of Oman. Review of Middle East Economics and Finance, 15(2), 1-9. http s://doi.org/10.1515/rmeef-2019-0012

Akçay, S., \& Karasoy, A. (2019). Determinants of remittances in Egypt: Do macroeconomic instability and oil price matter? International Migration, 57(5), 142-160. https://doi.org/10.1111/imig.12625

Cooray, A., \& Mallick, D. (2013). International business cycles and remittance flows. The B.E. Journal of Macroeconomics, 13(1), 515-547. https://doi.org/1 0.1515/bejm-2013-0030

Herrera, A. M., Lagalo, L. G., \& Wada, T. (2015). Asymmetries in the response of economic activity to oil price increases and decreases? Journal of International Money and Finance, 50, 108-133. http s://doi.org/10.1016/j.jimonfin.2014.09.004

IMF. (2019). IMF Country Report (Saudi Arabia), No. 19/291. IMF.

Kabundi, A., \& Ohnsorge, F. (2020). Implications of Cheap Oil for Emerging Markets (Policy Research Working Paper; No. 9403). World Bank. https://doi.or g/10.1596/1813-9450-9403

Lee, J., \& Strazicich, M. C. (2003). Minimum Lagrange multiplier unit root test with two structural breaks. Review of Economics and Statistics, 85(4), 1082-1089. https://doi.org/10.1162/003465303772815961

Naufal, G. S., \& Genc, I. (2012). Remittance Outflows. In G. S. Naufal \& I. Genc (Eds.), Expats and the Labor Force (pp. 77-95). Palgrave Macmillan. https://doi.or g/10.1057/9781137117854_5
Naufal, G. S., \& Termos, A. (2009). The

responsiveness of remittances to price of oil: The case of the GCC. OPEC Energy Review, 33(3-4), 184-197. ht tps://doi.org/10.1111/j.1753-0237.2009.00166.x

Pesaran, M. H., Shin, Y., \& Smith, R. J. (2001). Bounds testing approaches to the analysis of level relationships. Journal of Applied Econometrics, 16(3), 289-326. https://doi.org/10.1002/jae.616

Plante, M., \& Traum, N. (2012). Time - Varying Oil Price Volatility and Macroeconomic Aggregates. Center for Applied Economics and Policy Research Working Paper 2012 - 002.

Shin, Y., Yu, B., \& Greenwood-Nimmo, M. (2014). Modelling Asymmetric Cointegration and Dynamic Multipliers in a Nonlinear ARDL Framework. In R. C. Sickles \& W. C. Horrace (Eds.), Festschrift in Honor of Peter Schmidt (Vol. 44, pp. 281-314). Springer New York. https://doi.org/10.1007/978-1-4899-8008-3_9

Snudden, S. (2018). International Remittances, Migration, and Primary Commodities. The World Economy, 41(11), 2934-2953. https://doi.org/10.1111/ twec. 12666

Snudden, S. (2019). Labor and behavior determinants of remittances in Saudi Arabia. Economic Notes, 48(3), e12145. https://doi.org/10.1111/ecno.12145

Svirydzenka, K. (2016). Introducing a New BroadBased Index of Financial Development. IMF Working Papers, 16(05), 1-43. https://doi.org/10.5089/9781513 $\underline{583709.001}$

United Nations, Department of Economic and Social Affairs, Population Division. (2019). International Migration 2019: Wall Chart (ST/ESA/SER/A/431).

World Bank. (2016). Migration and Remittances Factbook 2016 (3rd ed.). The World Bank.

World Bank. (2020). World Development Indicators. htt p://databank.worldbank.org/data/home.aspx 